\title{
Development of an off-grid solar energy powered reverse osmosis desalination system for continuous production of freshwater with integrated photovoltaic thermal (PVT) cooling
}

\author{
Alireza Abbassi Monjezi ${ }^{1}$, Yingxue Chen ${ }^{1}$; R. Vepa ${ }^{1}$; Abd El-Hady B. Kashyout ${ }^{2}$, Gasser Hassan ${ }^{2}$, Hassan \\ El-BannaFath ${ }^{3}$, Abd El-WahabKassem ${ }^{4}$, Mohammad Hasan Shaheed*1

\begin{abstract}
${ }^{1}$ School of Engineering and Materials Science, Queen Mary University of London, Mile End Road, London, E1 4NS, UK ${ }^{2}$ City of Scientific Research and Technological Applications (SRTA-City), Alexandria, Egypt ${ }^{3}$ Egypt-Japan University for Science and Technology (E-Just), Egypt

${ }^{4}$ Faculty of Agriculture, Alexandria University, Egypt
\end{abstract}

\begin{abstract}
Increasing urbanisation and population growth have caused depletion of freshwater resources leading to exacerbation of water scarcity in remote communities. Whilst much attention has been paid to improving industrial-scale desalination plants over the past decade, the development of small-scale off-grid desalination units to facilitate freshwater supply for remote communities has been overlooked. This study presents a novel method for coupling solar photovoltaic thermal (PVT) cells to reverse osmosis (RO) desalination introducing seawater as the cooling medium to increase the thermal efficiency of solar energy generation and subsequently maximising the rate of freshwater production. The inclusion of a battery unit will enable a constant rate of freshwater supply leading to minimisation of membrane fouling which often occurs in renewable energy powered membrane desalination units. The integrative system has been simulated for the seawater properties and climatic conditions in Alexandria, Egypt. Furthermore, the modelling results indicate that using the proposed method will lead to a reduction of $0.12 \mathrm{kWh} / \mathrm{m}^{3}$ in the specific electricity consumption rate of RO desalination, as well as increasing the electricity generation capacity of the PVT cells leading to a 6\% reduction in the required solar panel surface area.
\end{abstract}

Keywords: Reverse osmosis; Desalination; PVT; Solar energy.

\footnotetext{
* Corresponding author.

Email address: m.h.shaheed@qmul.ac.uk (M.H.Shaheed)
} 


\section{Nomenclature}

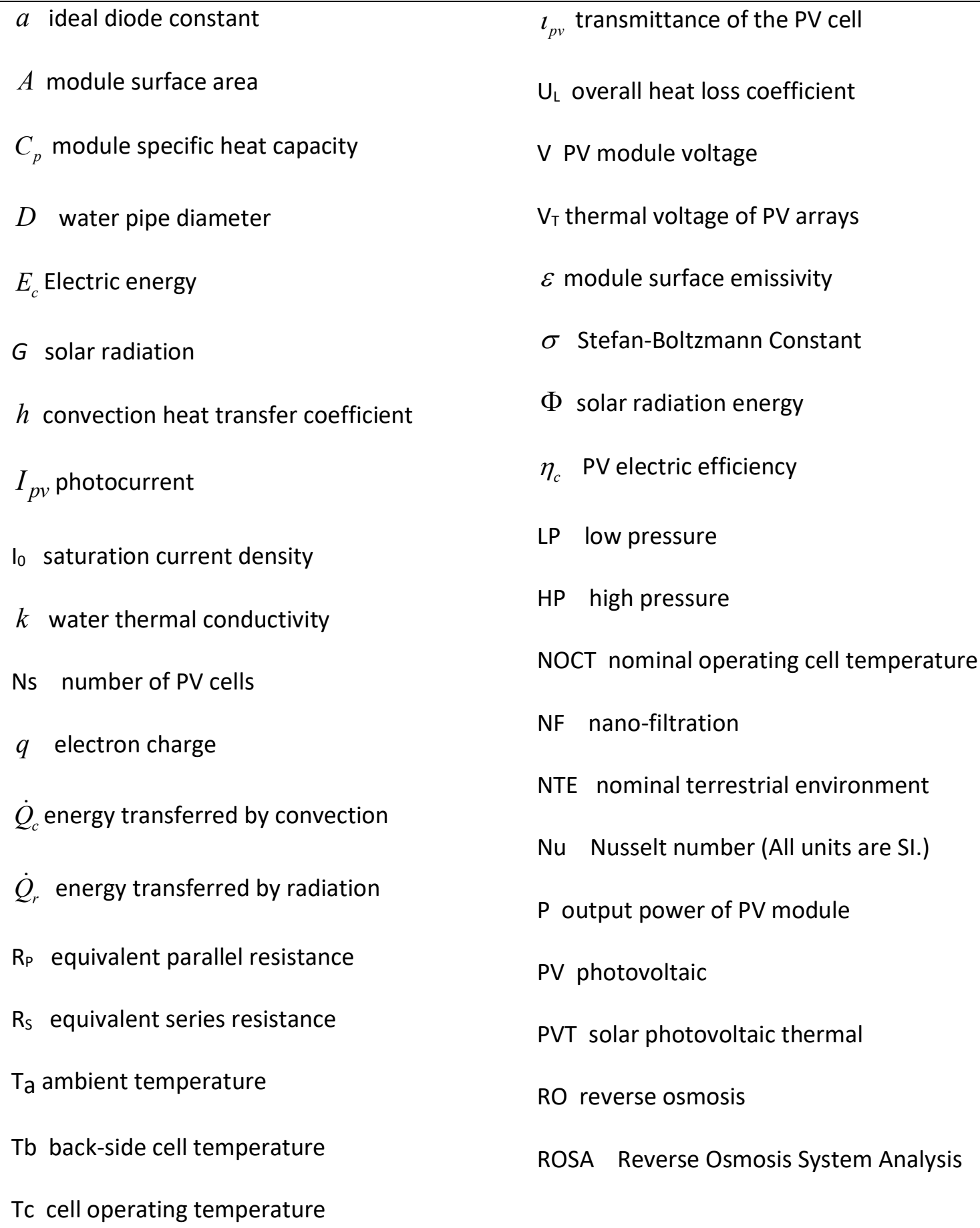

Tc cell operating temperature

\section{Introduction}

The developments in desalination techniques have resulted in the construction of many plants across the globe in order to meet the rising freshwater demands for drinking, sanitation and irrigation 
purposes. Whilst centralised solutions focus on the provision of clean water for large urban populations, the supply of freshwater to rural communities is threatened by the depletion of groundwater resources which have been relied upon for centuries. Urbanisation has also led to pollution of many rivers and aquifers carrying freshwater to remote areas and hence causing further scarcity. Osmosis based membrane processes offering compactness and reliability for sustained operation can contribute towards addressing this predicament. However, the considerable electricity requirements and thus reliance on existing infrastructure of pressure driven processes such as reverse osmosis (RO) and nano-filtration (NF) are the main bottlenecks of employing these technologies in remote areas and hence, there have been many studies in recent years focusing on off-grid desalination systems (Beitelmal and Fabris, 2015; Karimi et al., 2015; Abbassi Monjezi et al., 2017; Ali et al., 2018).

PV systems have previously been identified as the most compelling renewable energy for coupling with RO (Mathioulakis et al., 2007). Such systems are currently in commercial use as several small capacity systems have been installed in isolated locations (Peñate et al., 2007; Subiela et al., 2009; Ghermandi and Messalem, 2009).

However, one of the challenges in operating PV systems is the maintenance of efficiency in light of rising temperatures. Many hours of high temperatures during the operation of a PV module (exceeding $45^{\circ} \mathrm{C}$ ) negatively impacts the power output of the PV cells as well as the battery unit. Therefore, the thermal regulation of PV modules is essential in the short-term as well as the longterms since the heating effect is compounded annually and the efficiency is deteriorated over the length of its service (Alghoul et al., 2016).

With high solar intensity and ambient temperature particularly in the Middle East and North Africa (MENA) region, it is vital to keep the photovoltaic operating temperature within a reasonable range. The PV performance can be enhanced with a cooling fluid by decreasing the PV operating temperature. The electric efficiency is therefore improved when thermal energy is extracted by the 
cooling fluid. Also, the PV system with a cooling module is considered as one of the cheapest ways to improve the PV efficiency (Skoplaki and Palyvos, 2009a).

Abdallah et al. (2005) studied an RO unit coupled to a photovoltaic system using the "Tracking" principle allowing East/West rotation of the PV field. With the introduction of such systems, the performance of the unit was increased by $15 \%$.

An experimental study was carried out to examine the effectiveness of a seawater cooled PVT cell. It was shown that seawater can achieve uniform cooling of the cell and therefore improving its electricity generation efficiency (Kroiß et al., 2014). However, the full extent of the effect of seawater temperature increase and the subsequent impact on its desalination was not quantified.

Another challenge in coupling RO systems with PV cells is the intermittency of power supply. Hence, the inclusion of a battery in the system will not only facilitate continuous production of water but also eliminates severe membrane fouling due to water starvation which is a common challenge in renewable energy powered RO systems as stated in previous studies (Ruiz-García and Nuez, 2020; Freire-Gormaly and Bilton, 2019). This paper aims to quantify the increase in the efficiency of PV cells and RO desalination s using seawater as the cooling medium for PV. A battery unit has also been included to ensure continuous production of potable water which can address membrane fouling due inconsistent supply of seawater. It is also expected that since the proposed cooling process will result in the solar panels operating nearer their optimum temperature range, their operating lifetime will be increased. The proposed system has been modelled for the climatic conditions of Alexandria, Egypt and is demonstrated in Fig. 1. 


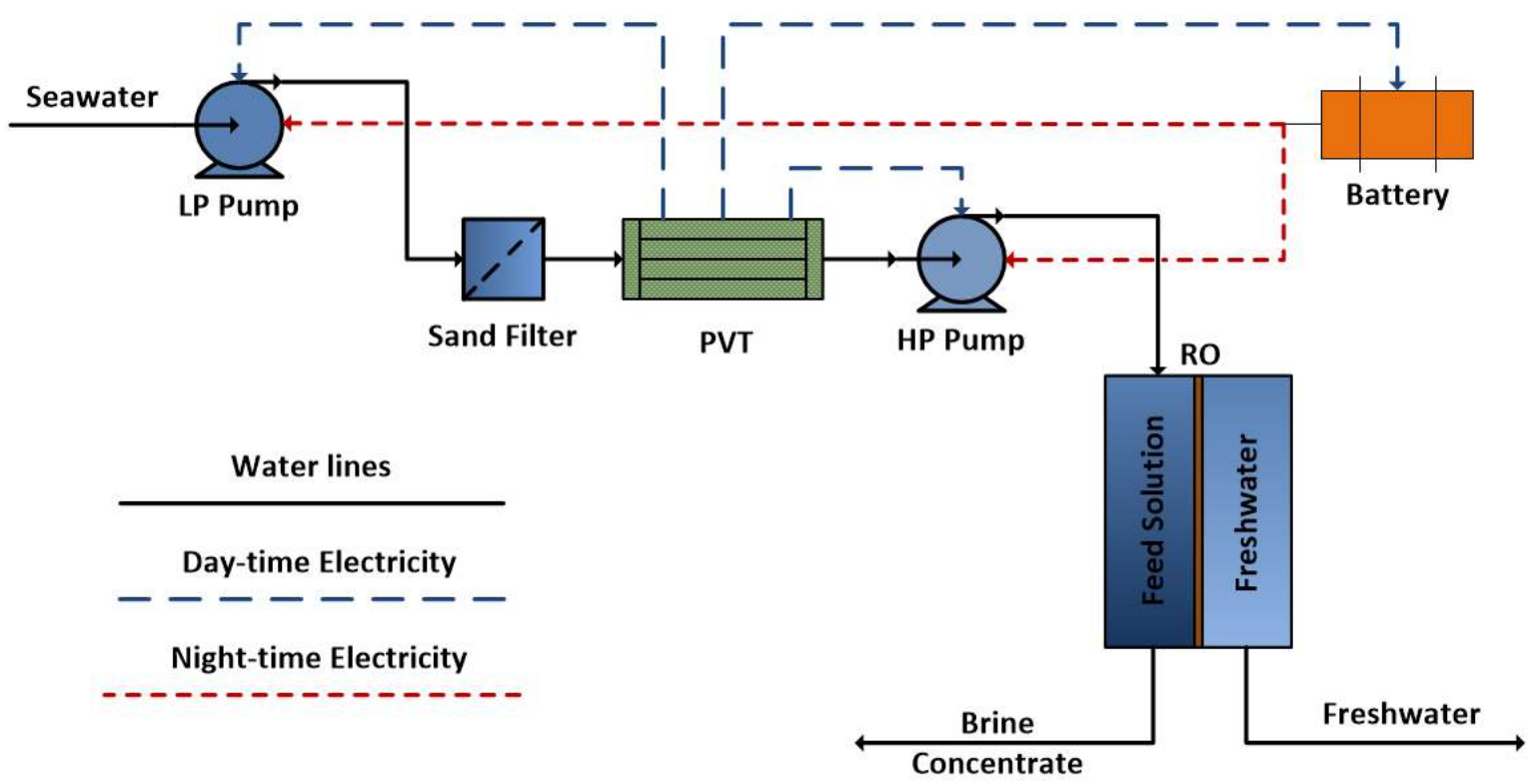

Fig.1: The proposed method of integrating reverse osmosis desalination with PVT solar energy generation including a battery unit to facilitate constant freshwater production rate.

As shown in Fig. 1, using a low-pressure (LP) pump the feed water is pumped to a sand filter providing an initial stage of filtration to remove the larger particles. The high pressure (HP) pump is then connected to the RO unit to provide the pressure driving force required to facilitate desalination through the semi-permeable membrane elements. Both the LP and HP pumps are powered by the PVT unit during day-time. The surplus electricity supplied by the PVT during day-time is stored in the battery unit which supplies the LP and HP pumps during night-time. Furthermore, the RO desalination unit has been designed for a freshwater production rate $5 \mathrm{~m}^{3} /$ day using the Reverse Osmosis System Analysis (ROSA) provided by Dow Water and Process Solutions whilst the PV module has been simulated through mathematical modelling on MATLAB.

\section{Operating temperature of photovoltaic module}

Several correlations based on the photovoltaic operating temperature as a function of solar irradiance and the ambient temperature have previously been developed. The elevated PV operating temperature leads to higher thermal power loss and lower electric efficiency. With an integrated 
cooling system, the heat can be transferred from the PV module to the ambient by mixed convection, including free convection to the surrounding air and forced convection to the coolant.

The purpose in this section is to analyse the transient operating temperature of the proposed PVT system with and without the coolant module (using MATLAB) and provide a comparison of the results. The climatic data used in this paper has been provided by the City of Scientific Research and Technological Applications (SRTA-City) team in Egypt for Alexandria in the 2015-2016 period. The water temperature in the Mediterranean near Alexandria varies from 16.8 to $21.8^{\circ} \mathrm{C}$. The feed water temperature was therefore set to $20^{\circ} \mathrm{C}$.

\subsection{Operating temperature of photovoltaic module without cooling system}

The operating temperature of PV cells are formulated with the nominal operating cell temperature (NOCT), which is measured under the following conditions of nominal terrestrial environment (NTE) : solar irradiation flux: $800 \mathrm{~W} / \mathrm{m}^{2}$, ambient temperature: $293.16 \mathrm{~K}\left(20^{\circ} \mathrm{C}\right)$, average wind speed: $1 \mathrm{~m} / \mathrm{s}$, open circuit (no electrical load), free-standing mounting frame, normal to the solar moon and given by (Tarabsheh et al., 2013; Spertino et al., 2016; Skoplaki and Palyvos, 2009):

$$
N O C T=\left(T_{c}-T_{a}\right)_{N T E}+20^{\circ} C .
$$

The value of NOCT is actually measured from PV cell samples, in which $T_{c}$ is the operating temperature of PV cells while $T_{a}$ is the ambient temperature.

Based on the climatic data obtained from SRTA-City, Fig.2 and Fig.3 present the mean ambient temperature and solar irradiance in the Borg El-Arab site near Alexandria, Egypt, respectively. 


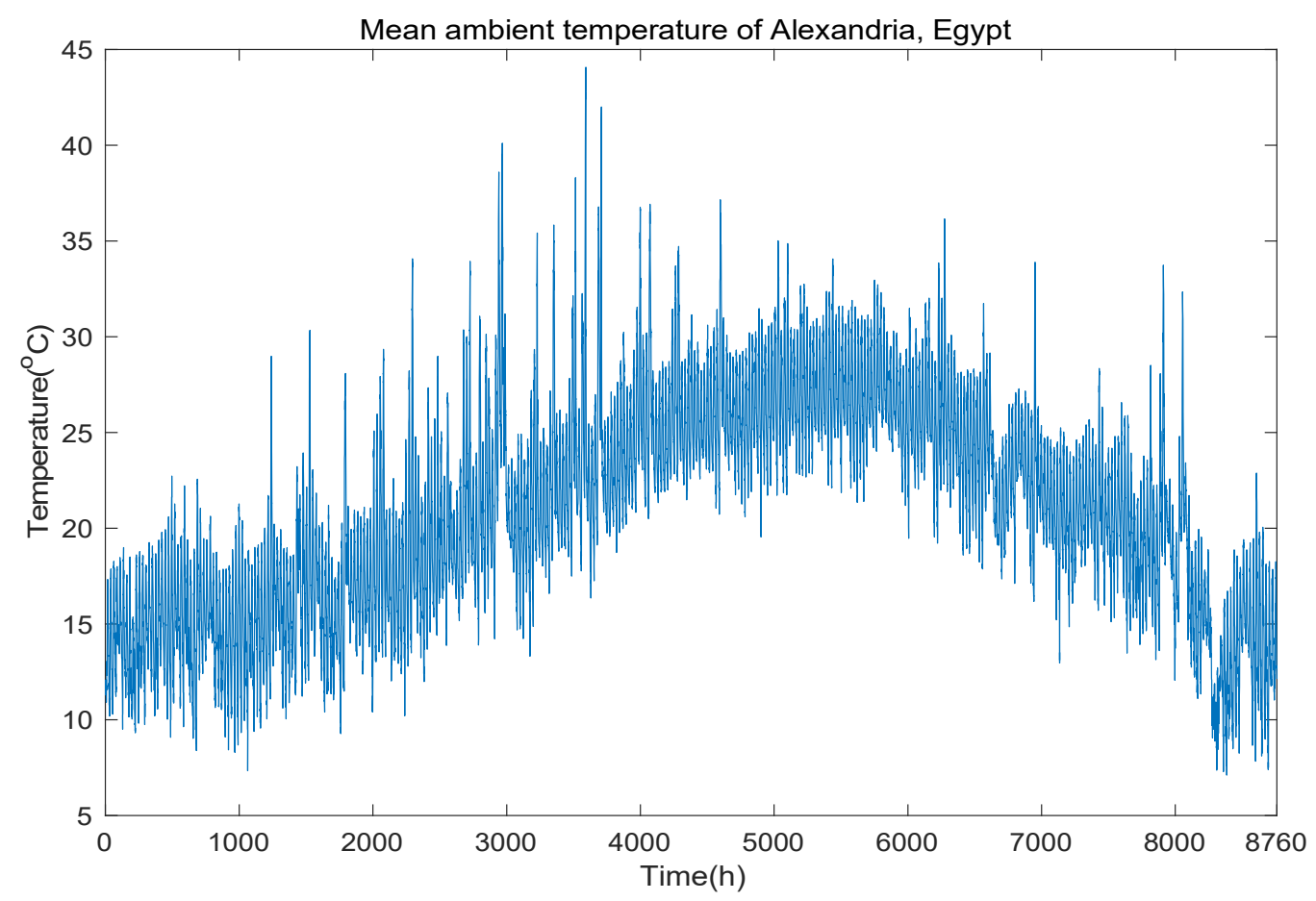

Fig.2. Mean ambient temperature of the location of the study, near Alexandria, Egypt, throughout the year obtained from average climatic data.

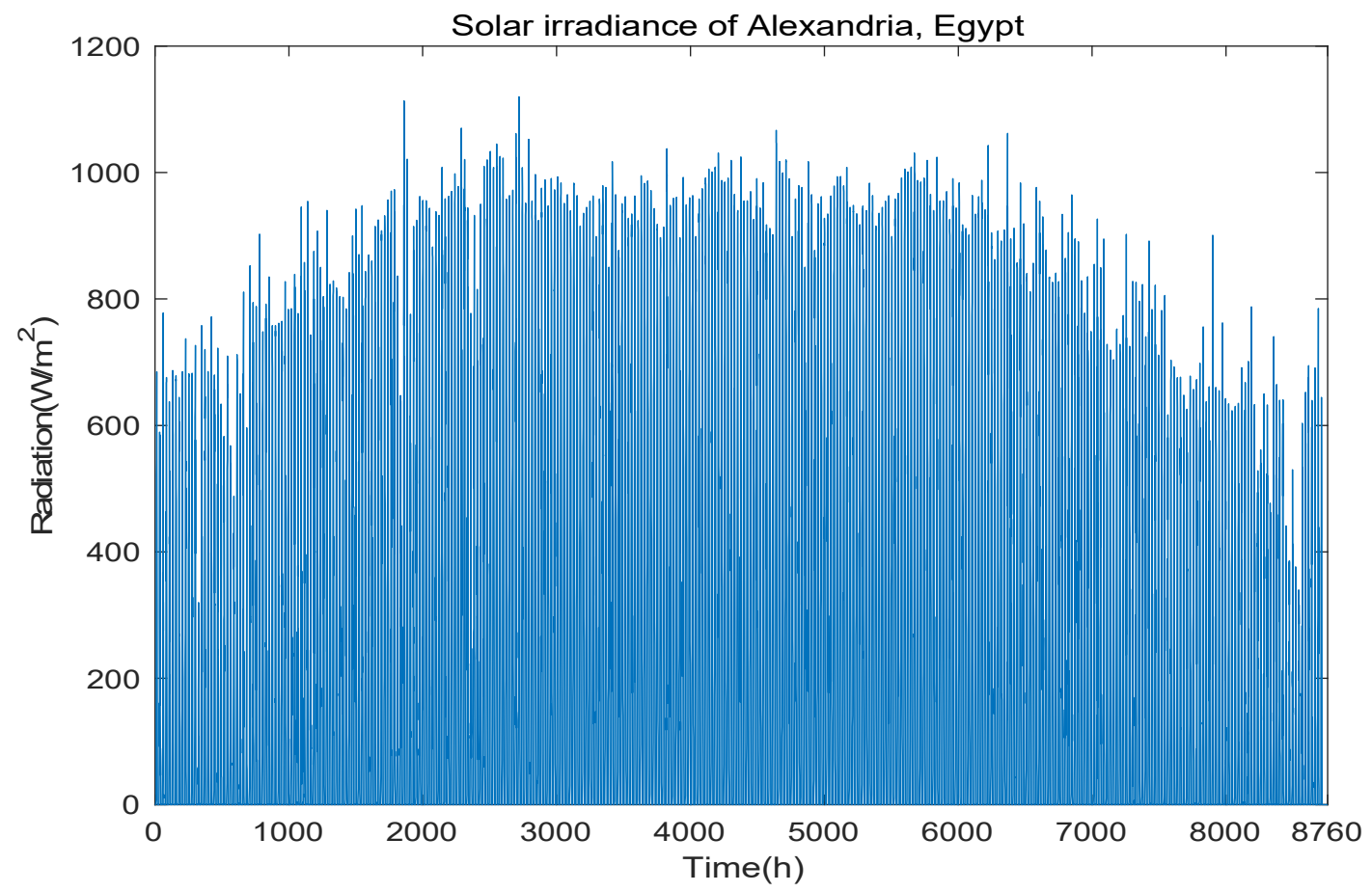

Fig.3. Solar irradiance of the location of the study, near Alexandria, Egypt, throughout the year obtained from average climatic data. 
Without cooling, the operating temperature of PV cells within a PV module has been previously investigated by several studies. Normally, the PV cell operating temperature is higher than the ambient temperature without a cooling system. In the analysis of previous studies, it is assumed that the temperatures on the PV cells are equal and are influenced by the ambient temperature and the solar irradiance. The expression to determine the transferred heat is as follows (Skoplaki and Palyvos, 2009a).

$$
Q_{c}=h \times A \times\left(T_{c}-T_{a}\right),
$$

where $h$ is the convection heat transfer coefficient, $T_{c}$ is the cell operating temperature, $T_{a}$ is the ambient temperature and $A$ is the module surface area. Typically, the operating temperature is much higher than the ambient temperature. A well-known expression for the PV operating temperature in terms of the NOCT is given as (Al Tarabsheh et al., 2016):

$$
T_{c}=T_{a}+\left(\frac{G_{T}}{G_{N O C T}}\right)\left(\frac{U_{L, N O C T}}{U_{L}}\right)\left(T_{N O C T}-T_{a, N O C T}\right) .
$$

In equation (3), $U_{L}$ is a constant, representing the overall heat loss coefficient at the cell temperature, (Skoplaki and Palyvos, 2009a), $U_{L, \text { NOCT }}$ is the corresponding heat loss at the NOCT, $G_{T}$ is solar irradiance at the cell operating temperature, $G_{N O C T}$ is the corresponding solar irradiance at the NOCT and $T_{a, N O C T}$ is the ambient temperature corresponding to the NOCT. A listing of other relevant equations for the PV module temperature $T_{c}$ can be found in the literature (Al Tarabsheh et al., 2016; Yang et al., 2012). Equation (3) can be simplified as follows:

$$
T_{c}=T_{a}+\left(\frac{G_{T}}{G_{N O C T}}\right)\left(T_{N O C T}-T_{a, N O C T}\right)
$$


Fig.4 depicts the mean ambient temperature and the mean operating temperature of a PV cell located in Alexandria, Egypt. The PV cell transient temperature $T_{c}$ is determined using MATLAB software.

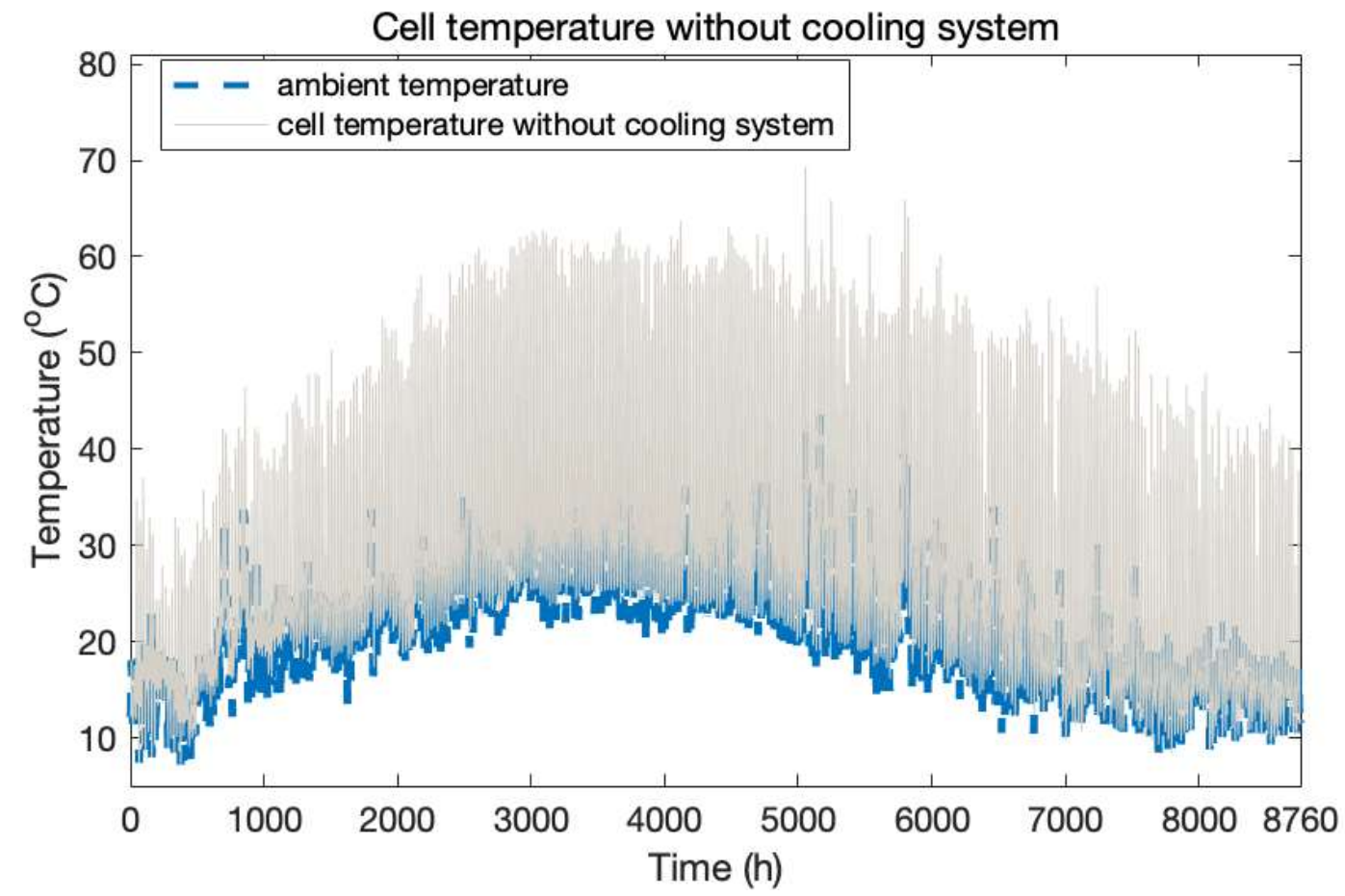

Fig.4. Simulation results presenting ambient temperature and the corresponding PV cell temperature throughout the year.

As shown in Fig.4, whilst moderate ambient temperatures of about $20^{\circ} \mathrm{C}$ exist the $\mathrm{PV}$ cell temperature can be highly elevated to above $40{ }^{\circ} \mathrm{C}$ posing a significant loss in the efficiency of the PV module.

\subsection{Operating temperature of photovoltaic module with cooling system}

The inclusion of a cooling system is beneficial owing to the variable characteristics of the photovoltaic cell under higher operating temperatures, resulting in various performance inefficiencies of the photovoltaic system. In this section, heat transfer between the cooling fluid, seawater in this study, and the PV cells is evaluated.

An integrated cooling system provides an important technique to keep PV modules at lower operating temperatures, so that the recovered thermal energy can be used to enhance the PV module efficiency. 
Also, the electrical energy output is improved to increase module effectiveness. The coolant is seawater from the PV module inlet, driven through a pump, with the temperature at $20^{\circ} \mathrm{C}$. This forced convection is added through the side of the PV module to extract heat. The heat transferred from solar radiation within the PV module is the same as which without the coolant (Al Tarabsheh et al., 2016).

The convection heat loss and radiation heat loss are defined as (Skoplaki and Palyvos, 2009a);

$$
\begin{gathered}
Q_{c}=h_{c} \times A \times\left(T_{c}-T_{a}\right), \\
Q_{r}=\varepsilon \times \sigma \times A \times\left(T_{c}^{4}-T_{a}^{4}\right),
\end{gathered}
$$

where $\varepsilon$ is PVT module surface emissivity $=0.9, \sigma$ is Stefan-Boltzmann Constant $=5.67 \times 10^{-8} \mathrm{~W} / \mathrm{m}^{2}$. The heat transfer of the coolant convection is given as a function of Nusselt number (Bejan, 2013) below.

$$
h_{w}=\frac{N u \times k}{D}
$$

In equation (7), $k$ and $D$ are water thermal conductivity $=0.58 \mathrm{~W} / \mathrm{m} \times k$ and water pipe diameter $(\mathrm{m})$, respectively. $N u$ is the Nusselt number $=4.36$. The temperature of the coolant increases linearly with the seawater flow direction (Yang et al., 2012). Electric energy $E_{c}$ is calculated by solar radiation energy $\Phi$ and PV electric efficiency $\eta_{c}$ and given by (Xu et al., 2013),

$$
E_{c}=\Phi \eta_{c}
$$

The actual temperature of the PV cell at any instant can be expressed by simply applying the energy balance as (Al Tarabsheh et al., 2016);

$$
\dot{T}_{c}=\frac{\Delta t}{\rho \nu C_{p}}\left(\alpha \Phi-\dot{Q}_{c}-\dot{Q}_{r}-E_{c}\right),
$$


where $C_{p}, \alpha, \dot{Q}_{c}, \dot{Q}_{r}$ are the module specific heat capacity, absorptivity, the energy transferred by convection and the energy transferred by radiation, respectively.

Due to the heat exchange in the process, the temperature of the cooling seawater from the outlet becomes higher than the temperature at the inlet. Though the PV cell has a varying performance as a result of the temperature gradient of the coolant flowing, previous experimental studies have verified that the whole PVT module is assumed to be a lumped system as the values are almost the same (Skoplaki and Palyvos, 2009b). Fig.5 shows the cell operating temperature without ( $\max 52{ }^{\circ} \mathrm{C}$ ) and with $\left(\max 39^{\circ} \mathrm{C}\right)$ an integrated cooling system, simulated for a period of one year (starting from $1^{\text {st }}$ January).

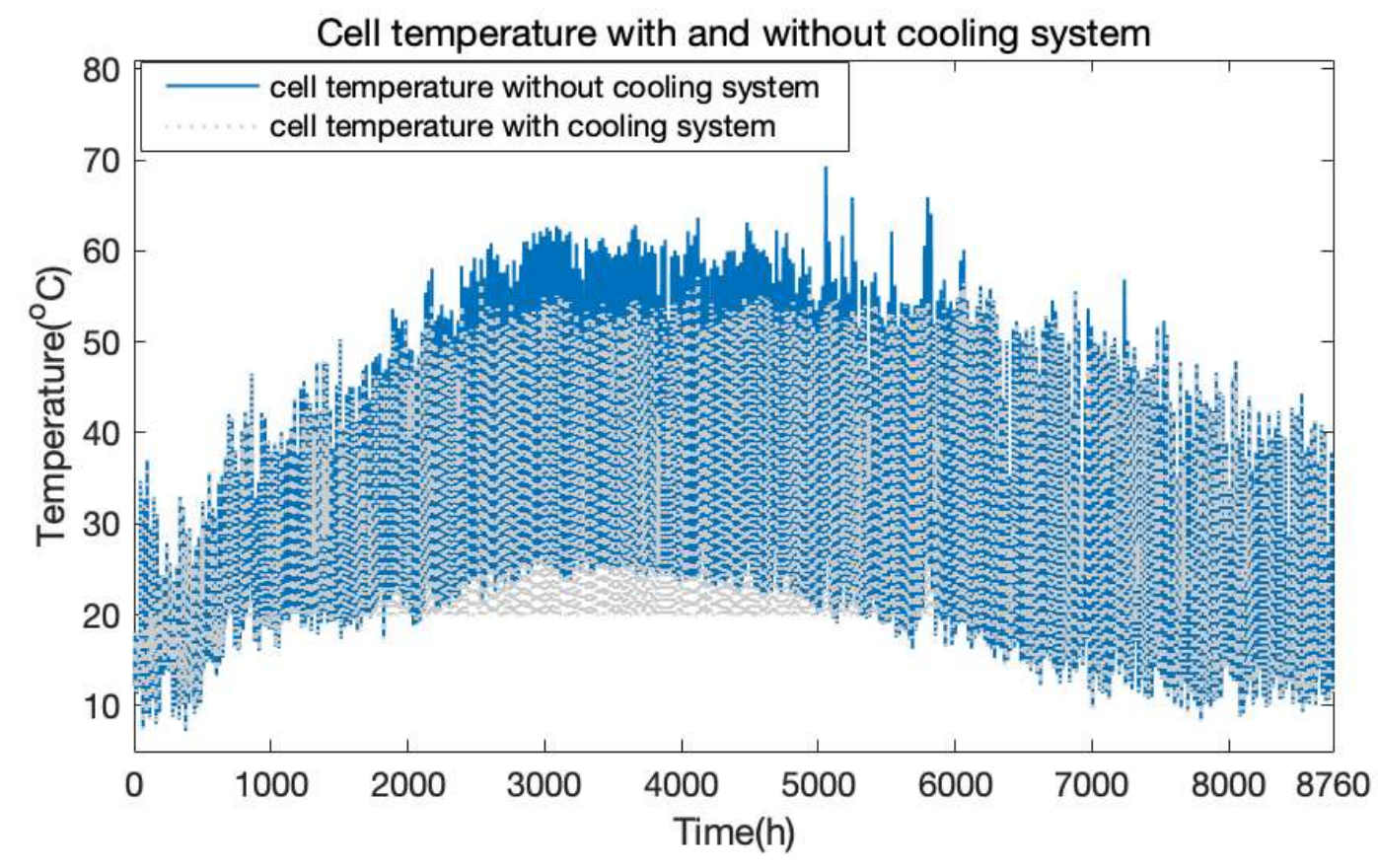

Fig. 5. Simulation results for the corresponding PV cell temperature with and without cooling for a period of one year.

The reduction of the module operating temperature, as demonstrated in Fig.5, will enhance the performance of the PV module in generating electricity as quantified in Section 5. 


\section{Photovoltaic model}

The prediction of electricity generation performance can be carried out using the photovoltaic model. The equivalent circuit of a typical PV device includes a current source, a diode, a parallel resistance and a series resistance. The calculation of each PV cell leads to an accurate description of the performance of the PV module. The current-voltage characteristic (I-V) is mathematically formulated as follows.

$$
I=I_{p v}-I_{0}\left\{\exp \left(\frac{V+R_{S} I}{v_{T} a}\right)-1\right\}-\left(\frac{V+R_{S} I}{R_{P}}\right)
$$

In equation(10) $I_{\mathrm{pv}}$ is the photocurrent, $I_{0}$ is the saturation current density, $\mathrm{V}$ is the applied voltage with $I$ being the resulting output current, $R_{s}$ is the equivalent series resistance and $R_{P}$ is the equivalent parallel resistance. $V_{T}=25.9 \mathrm{mV}$ is the thermal voltage of $\mathrm{PV}$ arrays and obtained from the following equation.

$$
V_{T}=N_{s} k T / q
$$

where $N_{S}$ is the number of PV cells connected in series, $q$ stands for the electron charge of value $1.6 \times 10^{-19}$ Coulombs, $a$ stands for ideal diode constant (typically between 1 and 2 ), $k$ stands for the Boltzmann constant with the value of $1.3806503 \times 10^{-23}, T$ stands for the $p$ - $n$ junction temperature in Kelvin.

The saturation current of the diode $\mathrm{I}_{0}$ is a temperature dependent parameter, which is calculated as follows (Kulaksiz, 2013).

$$
I_{0}=I_{\text {nom }}\left(\frac{T_{C}}{300}\right)^{3} e^{\left(\frac{T_{C}}{300}-1\right)\left(\frac{E_{g}}{n} V_{t}\right)}
$$




\section{Efficiency performance of photovoltaic cells}

When the module is heated, the band gap of the PV cell will decrease resulting in a significant reduction in the open circuit voltage. The open circuit voltage is one of the most influenced electrical parameters which affects the electric efficiency. Thus, by adjusting the operating temperature of the PV module with the cooling system, the electric efficiency of the module can be improved. In other words, the decreased thermal energy loss results in an enhanced effectiveness in the PV system.

The pronounced effect that PV operating temperature has upon PV electrical efficiency is well documented. Electrical efficiency $\eta_{c}$ is a function of the operating temperature $T_{c}$, and this efficiency is reduced when the module temperature increases, which leads to a linear relation in the following form eqn. (13) (Skoplaki and Palyvos, 2009; Xu et al., 2013; Atheaya et al., 2015).

$$
\eta_{c}=\eta_{T_{r e f}}-\left[\beta_{r e f} \times \eta_{T_{r e f}} \times\left(T_{c}-T_{r e f}\right)\right]
$$

In the above expression, $\eta_{T_{\text {ref }}}$ represents the electrical efficiency at the solar irradiation $1000 \mathrm{~W} / \mathrm{m}^{2}$ and at the reference temperature $T_{\text {ref }}$ while $\beta_{\text {ref }}$ denotes solar radiation coefficient. The values of $T_{\text {ref }}$ and $\beta_{\text {ref }}$ are normally provided by the module's manufacturer. From Skoplaki and Palyvos (2009b), $T_{\text {ref }}$ is taken as $25^{\circ} \mathrm{C}$, while $\eta_{T_{r e f}}$ and $\beta_{r e f}$ are $15.5 \%$ and $0.44 \%{ }^{\circ} C^{-1}$ at $T_{r e f}$ respectively. Furthermore, the quantities of $\eta_{T_{\text {ref }}}$ and $\beta_{\text {ref }}$ are $12 \%$ and $0.45 \%{ }^{\circ} \mathrm{C}^{-1}$ respectively when $T_{\text {ref }}$ is $25^{\circ} \mathrm{C}$.

\section{Power output of photovoltaic cells}

The circulating cooling fluid results in a lower PV module operating temperature and a higher production rate of the electrical power (Nualboonrueng et al., 2012). The basic correlation for the output power is the following (Xu et al., 2013).

$$
P=G_{T} l_{p v} \eta_{c}
$$


where $l_{p v}$ is the transmittance of the PV cell. A list of the PV electrical power correlations is well documented by Al Tarabsheh et al. (2016) as a function of the PV operating temperature and other variables. Fig. 6 depicts the generated power throughout the year with and without the coolant.

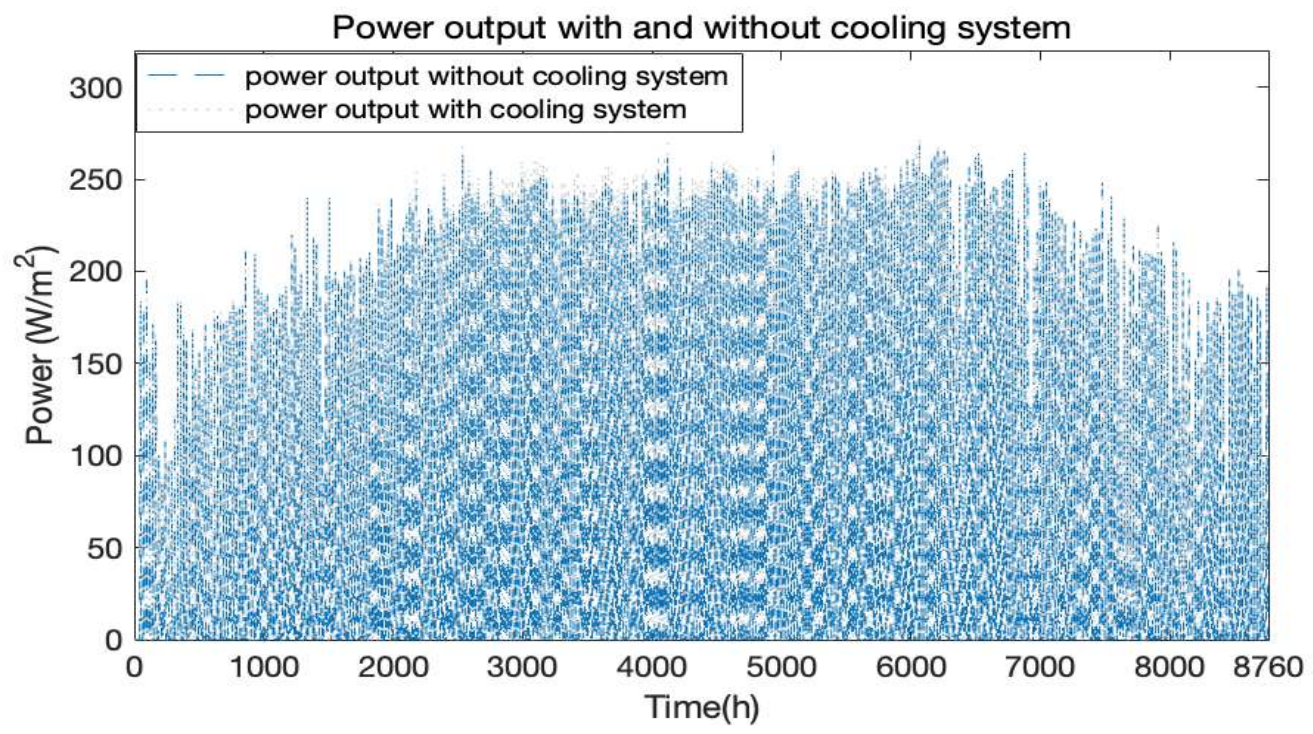

Fig. 6. Power output of the PVT module with and without an integrated cooling system.

Moreover, as mentioned previously the unit has been designed to supply a constant rate of power and therefore freshwater during day-time and night-time throughout the year in order to prevent membrane fouling. This is facilitated by the inclusion of a battery unit. The rate of output power from the PV unit integrated with a battery unit across the year is illustrated in Fig.7.

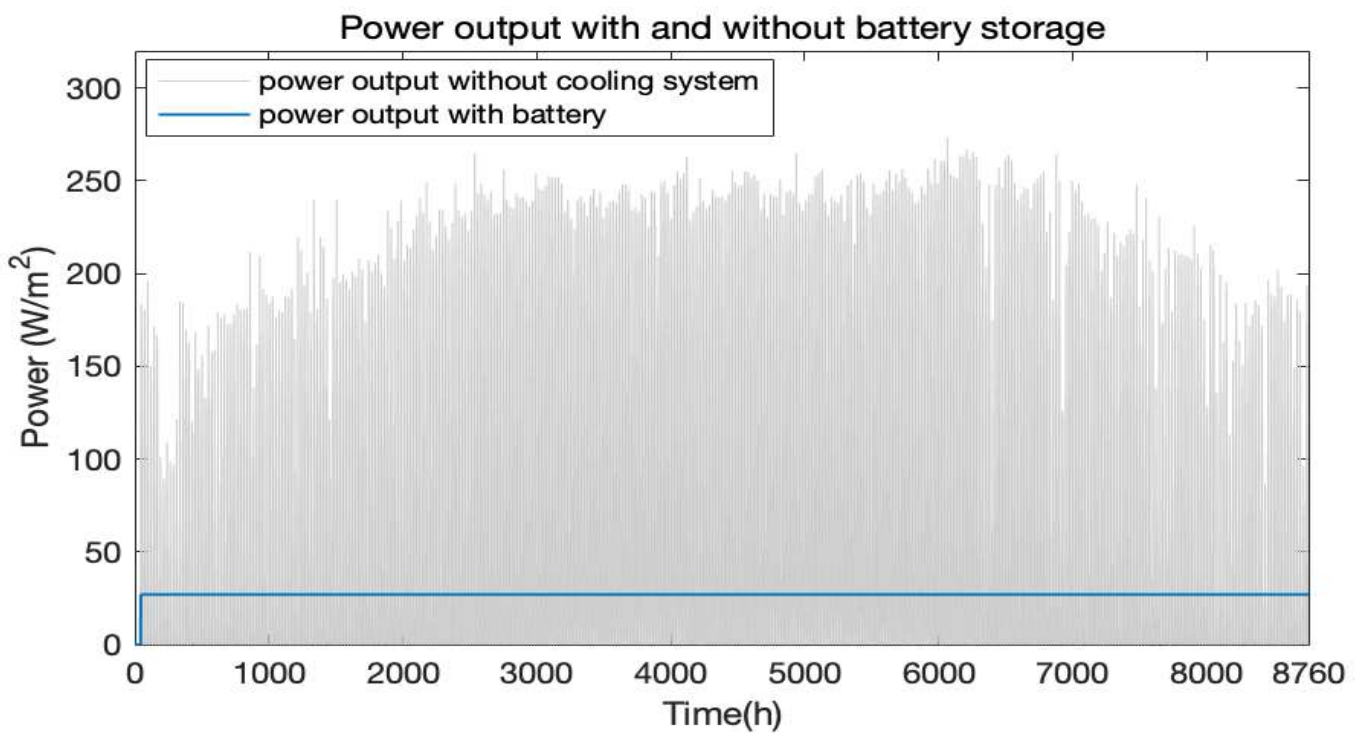

Fig. 7. The output power of the PVT module with a battery unit. 


\section{Desalination unit modelling}

The modelling of the desalination unit has been carried out on ROSA 9.1 made available by Dow Water and Process Solutions. A $5 \mathrm{~m}^{3}$ per day single-stage desalination unit with a $40 \%$ recovery rate has been simulated based on the water properties obtained from a beach well in Alexandria, Egypt, provided by the SRTA-City. The employed membrane is the Film Tech SW30-2540 with a required membrane area of $10.40 \mathrm{~m}^{2}$. The composition and properties of the seawater feed, the freshwater permeate and the concentrate without and with PVT cooling are provided in Table 1 and Table 2, respectively.

Table 1: Composition and properties of the seawater feed, brine concentrate and freshwater permeate obtained from ROSA 9.1 for the specified $5 \mathrm{~m}^{3}$ /day RO desalination unit WITHOUT the feed seawater cooling the PVT module.

\begin{tabular}{|c|c|c|c|}
\hline ion & Feed $(\mathrm{mg} / \mathrm{L})$ & Concentrate $(\mathrm{mg} / \mathrm{L})$ & Permeate (mg/L) \\
\hline $\mathrm{K}^{+}$ & 168.00 & 277.24 & 4.13 \\
\hline $\mathrm{Na}^{+}$ & 10562.00 & 17520.94 & 123.48 \\
\hline $\mathrm{Mg}^{2+}$ & 838.00 & 1394.70 & 2.94 \\
\hline $\mathrm{Ca}^{2+}$ & 653.00 & 1086.84 & 2.24 \\
\hline $\mathrm{Sr}^{2+}$ & 0.00 & 0.00 & 0.00 \\
\hline $\mathrm{Ba}^{2+}$ & 0.00 & 0.00 & 0.00 \\
\hline $\mathrm{CO}_{3}^{2-}$ & 5.85 & 12.24 & 0.00 \\
\hline $\mathrm{HCO}_{3}^{-}$ & 160.00 & 257.89 & 5.60 \\
\hline $\mathrm{NO}_{3}^{-}$ & 0.00 & 0.00 & 0.00 \\
\hline $\mathrm{Cl}^{-}$ & 14079.00 & 29784.46 & 200.83 \\
\hline $\mathrm{F}^{-}$ & 0.00 & 0.00 & 0.00 \\
\hline $\mathrm{SO}_{4}{ }^{2-}$ & 2692.00 & 4484.27 & 3.57 \\
\hline $\mathrm{SiO}_{2}$ & 0.00 & 0.00 & 0.00 \\
\hline$B^{-}$ & 0.00 & 0.00 & 0.00 \\
\hline $\mathrm{CO}_{2}$ & 2.35 & 3.95 & 2.65 \\
\hline $\mathrm{NH}_{3}$ & 0.00 & 0.00 & 0.00 \\
\hline $\mathrm{NH}_{4}^{+}$ & 0.00 & 0.00 & 0.00 \\
\hline TDS & 29157.86 & 54818.59 & 342.81 \\
\hline $\mathrm{pH}$ & 7.60 & 7.56 & 6.49 \\
\hline
\end{tabular}


Table 2: Composition and properties of the seawater feed, brine concentrate and freshwater permeate obtained from ROSA 9.1 for the specified $5 \mathrm{m3}$ /day RO desalination unit WITH the feed seawater cooling the PVT module.

\begin{tabular}{|c|c|c|c|}
\hline ion & Feed $(\mathrm{mg} / \mathrm{L})$ & Concentrate $(\mathrm{mg} / \mathrm{L})$ & Permeate (mg/L) \\
\hline $\mathrm{K}^{+}$ & 168.00 & 276.38 & 5.43 \\
\hline $\mathrm{Na}^{+}$ & 10562.00 & 17495.27 & 162.11 \\
\hline $\mathrm{Mg}^{2+}$ & 838.00 & 1394.09 & 3.86 \\
\hline $\mathrm{Ca}^{2+}$ & 653.00 & 1086.37 & 2.95 \\
\hline $\mathrm{Sr}^{2+}$ & 0.00 & 0.00 & 0.00 \\
\hline $\mathrm{Ba}^{2+}$ & 0.00 & 0.00 & 0.00 \\
\hline $\mathrm{CO}_{3}^{2-}$ & 5.85 & 12.73 & 0.00 \\
\hline $\mathrm{HCO}_{3}^{-}$ & 160.00 & 255.73 & 7.28 \\
\hline $\mathrm{NO}_{3}{ }^{-}$ & 0.00 & 0.00 & 0.00 \\
\hline $\mathrm{Cl}^{-}$ & 14079.00 & 29742.70 & 263.67 \\
\hline $\mathrm{F}^{-}$ & 0.00 & 0.00 & 0.00 \\
\hline $\mathrm{SO}_{4}{ }^{2-}$ & 2692.00 & 4483.54 & 4.70 \\
\hline $\mathrm{SiO}_{2}$ & 0.00 & 0.00 & 0.00 \\
\hline$B^{-}$ & 0.00 & 0.00 & 0.00 \\
\hline $\mathrm{CO}_{2}$ & 2.18 & 4.09 & 2.60 \\
\hline $\mathrm{NH}_{3}$ & 0.00 & 0.00 & 0.00 \\
\hline $\mathrm{NH}_{4}^{+}$ & 0.00 & 0.00 & 0.00 \\
\hline TDS & 29157.86 & 54746.86 & 449.95 \\
\hline $\mathrm{pH}$ & 7.60 & 7.50 & 6.57 \\
\hline
\end{tabular}

The variation in the specific energy consumption of the units with and without integrated PVT cooling is demonstrated in Table 3. It is shown that if the temperature of the feed water is raised by $5^{\circ} \mathrm{C}$ due 
to undergoing PVT cooling, the specific energy consumption of the desalination unit is reduced by 0.12 $\mathrm{kWh} / \mathrm{m}^{3}$ of desalinated water. This phenomenon is due to the reduced viscosity of the feed water from $1.23 \mathrm{cP}$ to $1.11 \mathrm{cP}$ as a result of the rise in the feed water temperature leading to raised permeability through the RO membrane. The specific energy consumption can be further reduced by employing an energy recovery device on the concentrate stream. However, given the small flow rates in the system for a $5 \mathrm{~m}^{3} /$ day unit, the use of an energy recovery device is not justified from a financial perspective and therefore omitted from the calculations in this study.

Table 3: Specific energy consumption of the RO desalination unit with and without PVT cooling.

Specific energy consumption of the RO desalination unit WITHOUT PVT cooling $\left(\mathrm{kWh} / \mathrm{m}^{3}\right)$ 4.27 Specific energy consumption of the RO desalination unit WITH PVT cooling $\left(\mathrm{kWh} / \mathrm{m}^{3}\right)$ 4.15

The financial implication of the variation in the desalination specific energy consumption due to PVT cooling can be shown by the reduction in the required square metre of solar panels. The required solar panel area to power the desalination unit with and without seawater cooling are now estimated and compared in Table 4. It is shown that for a $5 \mathrm{~m}^{3} /$ day RO desalination unit, the integrated cooling system proposed in this study will result in a $6 \%$ reduction in the required solar panel area indicating a $6 \%$ gain in electricity generation. Such reduction will lead to substantial savings in terms of capital costs incurred in solar PVT desalination systems using reverse osmosis.

Table 4: The required solar panel areas to power the RO desalination unit with and without seawater cooling.

\begin{tabular}{|l|l|}
\hline Required area of solar panels WITHOUT PVT cooling $\left(\mathrm{m}^{2}\right)$ & 19.3 \\
\hline Required area of solar panels WITH PVT cooling $\left(\mathrm{m}^{2}\right)$ & 18.1 \\
\hline
\end{tabular}

The overall efficiency gains based on the proposed integrated PVT cooling with the RO seawater feed are presented in Fig. 8. It is demonstrated that the proposed method will simultaneously raise the efficiency of PVT solar energy generation and RO seawater desalination. 


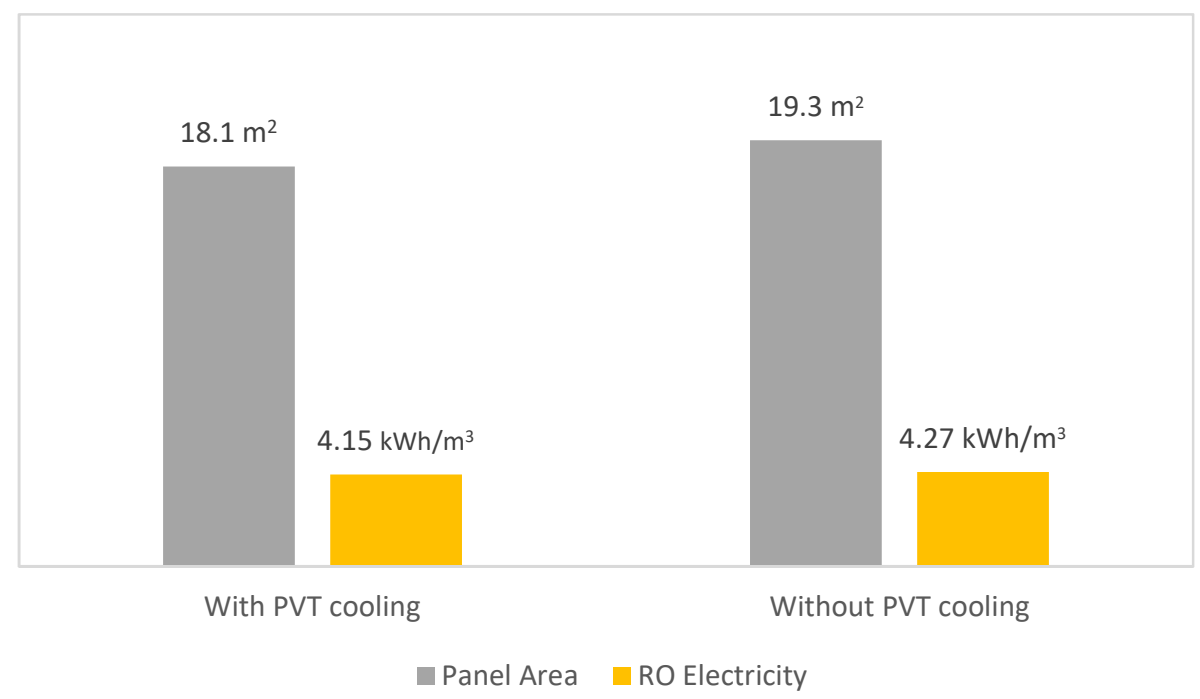

Fig. 8. The results of both reverse osmosis desalination and PVT solar energy generation with and without the integrated PVT cooling by seawater.

\section{Conclusions}

This study introduces a novel PVT cooling method integrated with reverse osmosis desalination leading to a simultaneous increase in the efficiency of both the solar energy generation modules and the desalination unit. This performance efficiency improvement has been quantified and presents a viable method for off-grid solar desalination, particularly in remote areas.

A $5 \mathrm{~m}^{3} /$ day RO desalination unit was designed and simulated using ROSA 9.1 software for seawater composition obtained from a beach well in Alexandria, Egypt. The required solar panel area with and without the cooling system is evaluated and compared for the same climatic conditions. It was demonstrated that a reduction of $0.12 \mathrm{kWh} / \mathrm{m}^{3}$ in the specific energy consumption of the RO unit can be achieved using the proposed PVT cooling leading to a $6 \%$ reduction in the required solar panel surface area.

The developed system, integrating a battery unit with the RO desalination and PVT modules, will be capable of producing clean water at a constant rate throughout the year as well as a constant rate during the day-time and night-time. Such mechanism will enable minimisation of membrane fouling since it will facilitate constant supply of feed water to the membrane. 
Further studies are suggested on the potential of concentrate minimisation. In this context, one of the methods could be to integrate a membrane distillation unit using the concentrate stream from the proposed system given that elevated concentrate temperatures can be achieved through further cooling of PV cells. In addition, the long-term impact of operating the PV cells at lower temperatures through cooling with seawater can provide further insight on the anticipated increase on the lifetime of PVT modules. The scalability of the proposed method for larger solar powered desalination plants is also recommended to be evaluated.

\section{Acknowledgments}

The financial support of the British Council in the UK and the Science and Technology Development Fund (STDF) in Egypt is gratefully acknowledged.

\section{References}

A. Abbassi Monjezi, H.B. Mahood, A.N. Campbell, (2017) "Regeneration of dimethylether as a draw solute in forward osmosis by utilising thermal energy from a solar pond,"Desalination 415,pp. 104-114.

S. Abdallah, M. Abu-Hilal, M.S. Mohsen, (2015) "Performance of a photovoltaic powered reverse osmosis system under local climatic conditions."Desalination 183, pp. 95-104.

M.A. Alghoul, P. Poovanaesvaran, M.H. Mohammed, A.M. Fadhil, A.F. Muftah, M.M. Alkilani, K. Sopian, (2016) "Design and experimental performance of brackish water reverse osmosis desalination unit powered by $2 \mathrm{~kW}$ photovoltaic system," Renewable Energy 93, pp. 101-114.

A. Al Tarabsheh, A. Ghazal, M. Asad, Y. Morci, I. Etier, A. El Haj, and H. Fath, (2016) "Performance of photovoltaic cells in photovoltaic thermal (PVT) modules," IET Renew. Power Gener., vol. 10, no. 7, pp. 1017-1023.

A. Ali, R.A. Tufa, F. Macedonio, E. Curcio, E. Drioli, (2018) "Membrane technology in renewableenergy-driven desalination, Renew. Sustain. Energy Rev. 81, pp. 1-21.

A.H. Beitelmal, D. Fabris, (2015) "Off-the grid solar-powered portable desalination system", Appl. Therm. Eng. 85, pp. 172-178.

A. Bejan, Convection Heat Transfer. Fourth Edition, Wiley, 2013. 
K. Bourouni, T. Ben M'Barek, A. Al Taee, (2011) “Design and optimization of desalination reverse osmosis plants driven by renewable energies using genetic algorithms," Renewable Energy 36, pp. 936-950.

A. Ghermandi, R. Messalem, (2009) "Solar-driven desalination with reverse osmosis: the state of the art,"Desalination and water treatment 7, pp. 285-296.

L. Karimi, L. Abkar, M. Aghajani, A. Ghassemi, (2015) “Technical feasibility comparison of off-grid PVEDR and PV-RO desalination systems via their energy consumption". Sep. Purif. Technol. 151, pp. 82-94.

A. Kroiß, A. Präbst, S. Hamberger, M. Spinnler, Y. Tripanagnostopoulos, T. Sattelmayer, (2014) "Development of a seawater-proof hybrid photovoltaic/thermal (PV/T) solar collector,"Energy Procedia 52, pp. 93-103.

A. A. Kulaksiz, (2013) "ANFIS-based estimation of PV module equivalent parameters: Application to a stand-alone PV system with MPPT controller," Turkish J. Electr. Eng. Comput. Sci., vol. 21, no. SUPPL. 2, pp. 2127-2140.

E. Mathioulakis, V. Belessiotis, E. Delyannis, (2007) “Desalination by using alternative energy: review and state-of-the-art."Desalination 203, pp. 346-65.

T. Nualboonrueng, P. Tuenpusa, Y. Ueda, and A. Akisawa, (2012) "Field experiments of PV-Thermal collectors for residential application in Bangkok," Energies, vol. 5, no. 4, pp. 1229-1244.

B. Peñate, F. Castellano, P. Ramírez, (2007) "PV-RO Desalination Stand-Alone System in the Village of Ksar Ghilène (Tunisia)", IDAWorld Congress, Maspalomas, Spain.

E. Skoplaki and J. A. Palyvos, (2009) "Operating temperature of photovoltaic modules: A survey of pertinent correlations," Renew. Energy, vol. 34, no. 1, pp. 23-29.

E. Skoplaki and J. A. Palyvos, (2009) "On the temperature dependence of photovoltaic module electrical performance: A review of efficiency/power correlations," Sol. Energy, vol. 83, no. 5, pp. 614-624.

V.J. Subiela, J.A. de la Fuente, G. Piernavieja, B. Peñate, (2009) Canary Islands Institute of Technology (ITC) experiences in desalination with renewable energies (1996-2008), Desalination and water treatment 7, 220-235.

D. J. Yang, Z. F. Yuan, P. H. Lee, and H. M. Yin, (2012) "Simulation and experimental validation of heat transfer in a novel hybrid solar panel," Int. J. Heat Mass Transf., vol. 55, no. 4, pp. 1076-1082.

M. Freire-Gormaly, A.M. Bilton, (2019) Impact of intermittent operation on reverse osmosis membrane fouling for brackish groundwater desalination systems, Membrane Science 583, 220 230.

A. Ruiz-García, I. Nuez (2020) Long-term intermittent operation of a full-scale BWRO desalination 
plant, Desalination 489, 114526.

D. Atheaya, A. Tiwari, G. N. Tiwari, and I. M. Al-Helal. 2015. "Analytical Characteristic Equation for Partially Covered Photovoltaic Thermal (PVT) Compound Parabolic Concentrator (CPC)." Solar Energy.

Skoplaki, E., and J. A. Palyvos. 2009. “On the Temperature Dependence of Photovoltaic Module Electrical Performance: A Review of Efficiency/Power Correlations." Solar Energy 83(5): 614-24. Spertino, Filippo et al. 2016. "Thermal-Electrical Model for Energy Estimation of a Water Cooled Photovoltaic Module." Solar Energy.

Tarabsheh, Anas Al et al. 2013. "Investigation of Temperature Effects in Efficiency Improvement of Non-Uniformly Cooled Photovoltaic Cells." In Chemical Engineering Transactions,.

Al Tarabsheh, Anas et al. 2016. "Performance of Photovoltaic Cells in Photovoltaic Thermal (PVT) Modules." IET Renewable Power Generation 10(7): 1017-23.

Xu, Xinqiang et al. 2013. "Performance and Reliability Analysis of Hybrid Concentrating Photovoltaic/Thermal Collectors with Tree-Shaped Channel Nets' Cooling System." IEEE Transactions on Components, Packaging and Manufacturing Technology. 